\title{
A baseline for the vertical distribution of the stable carbon isotopes of dissolved inorganic carbon $\left(\delta^{13} C_{\text {DIC }}\right)$ in the Arctic Ocean
}

\author{
D. Bauch ${ }^{1} \cdot$ L. Polyak ${ }^{2} \cdot$ J. D. Ortiz
}

Published online: 23 November 2015

(c) Springer-Verlag Berlin Heidelberg 2015

\begin{abstract}
Stable carbon isotopes of dissolved inorganic carbon $\left(\delta^{13} \mathrm{C}_{\text {DIC }}\right)$ in the ocean are generally not well understood as they are governed by a complex interplay of biological processes and air-sea exchange. In the Arctic Ocean, $\delta^{13} C_{\text {DIC }}$ values are prone to change in the near future with rapidly changing climate conditions. This study provides a baseline to assess the $\delta^{13} \mathrm{C}_{\text {DIC }}$ of the Arctic Ocean with a focus on upper to intermediate waters (to $\sim 500 \mathrm{~m}$ ). Measured $\delta^{13} \mathrm{C}_{\text {DIC }}$ values in the Arctic Ocean range from $\sim-0.6$ to $+2.2 \%$. In the Eurasian Basin, the $\delta^{13} \mathrm{C}_{\text {DIC }}$ values lie between $\sim 1$ and $1.5 \%$ and exhibit little variation within the upper layers. In the Canada Basin, $\delta^{13} \mathrm{C}_{\text {DIC }}$ values reach $2 \%$ in the surface layer, with lowest values of $\sim-0.6 \%$ found at $\sim 200 \mathrm{~m}$ water depth. At greater depth, $\delta^{13} \mathrm{C}_{\text {DIC }}$ values range from $\sim 1$ to $1.5 \%$ within both basins. In the Canada Basin, nutrient levels are higher than in the Eurasian Basin and associated variations in $\delta^{13} C_{\text {DIC }}$ are clearly related to biological processes. However, low $\delta^{13} \mathrm{C}_{\mathrm{DIC}}$ values in the Canada Basin are also strongly influenced by non-equilibrium air-sea exchange processes. The different $\delta^{13} \mathrm{C}_{\text {DIC }}$ patterns between the Canada Basin and the Eurasian Basin appear to be linked to differences in transport processes within the Arctic Ocean
\end{abstract}

D. Bauch

dbauch@geomar.de

J. D. Ortiz

jortiz@kent.edu

1 GEOMAR Helmholtz Centre for Ocean Research Kiel, Wischhofstr. 1-3, 24148 Kiel, Germany

2 Byrd Polar and Climate Research Center, Ohio State University, 1090 Carmack Rd., Columbus, OH 43210, USA

3 Department of Geology, Kent State University, 221 McGilvrey Hall, Kent, OH 44242, USA halocline. The upper layers in the Canada basins have direct contributions of waters from the Laptev, East Siberian and Chukchi shelves, which contain elevated fractions of river waters and sea-ice related brines, whereas their counterparts, in the Eurasian Basin, are mostly formed by halocline waters from the Barents and Kara seas. River waters have low $\delta^{13} \mathrm{C}_{\mathrm{DIC}}$ of $\sim-8 \%$ on average, but in the Arctic basins this signal is mostly lost and $\delta^{13} \mathrm{C}_{\mathrm{DIC}}$ values show only a weak correlation to river water fractions contained in the water mass. No relation between $\delta^{13} \mathrm{C}_{\mathrm{DIC}}$ and sea-ice related brine contribution is apparent.

Keywords Arctic Ocean $\cdot \delta^{13} \mathrm{C}_{\text {DIC }} \cdot$ Air-sea gas exchange - Suess effect - Anthropogenic $\mathrm{pCO}_{2}$ invasion . Water masses

\section{Introduction}

Stable carbon isotopes of dissolved inorganic carbon $\left(\delta^{13} \mathrm{C}_{\text {DIC }}\right)$ in the Arctic Ocean are likely to change in the near future with rapidly changing climate conditions. Climate reconstructions of the recent geological past characterize our climate system under different preconditions and aid to better evaluate the modern climate change and its future projections. For paleoclimate reconstructions, stable isotopes of carbonate shells preserved within the sediments provide a powerful tool (e.g., [46]). While the factors controlling oxygen isotopes $\left(\delta^{18} \mathrm{O}\right)$ in carbonate shells in the Arctic are reasonably well understood (e.g., [51]), this is not the case for stable carbon isotopes $\left(\delta^{13} \mathrm{C}\right)$. Furthermore, we have only a rudimentary understanding of the complex interplay of biological and physical-chemical factors influencing the $\delta^{13} \mathrm{C}_{\text {DIC }}$ that is recorded in the $\delta^{13} \mathrm{C}$ of carbonate shells (e.g., [27, 43]). With the ongoing 
climate change and the accompanying changes in Arctic hydrography as well as biological productivity and communities, it is important to assess and further understand the modern distribution of $\delta^{13} \mathrm{C}_{\mathrm{DIC}}$ in the Arctic Ocean. We note that the rapid pace of changes in the Arctic system dictates urgency in the baseline assessment of its components.

One of the most pronounced manifestations of the global climate change is the recent dramatic decline of the Arctic summer sea-ice extent (e.g., [16, 47]). This situation indicates that the Arctic environment is especially sensitive to climate change and that significant further changes may occur in this part of the Earth in the near future as feedback reactions (e.g., [13, 24]). Under present conditions, Arctic sea ice is mainly produced over the broad continental shelves that cover nearly half of the Arctic Ocean area and, to a large extent, are seasonally free of sea ice (e.g., [29]). Areas of seasonal ice distribution over the Arctic shelves can also have high biological productivity (e.g., [25, 41]. Alterations in the Arctic sea-ice cycle have a considerable hydrographic impact as changes in sea-ice extent and production affect the formation of brines and contribution of sea-ice melt to the water column (e.g., [8]) and all these changes may also impact air-sea exchange. Changes in sea-ice seasonality are also likely to have a dramatic effect on Arctic biological production and communities. Some biological aspects of the ongoing Arctic change have already been detected and more are expected to follow (e.g., $[5,21,45,50])$.

An additional factor to consider for the evaluation of $\delta^{13} \mathrm{C}_{\text {DIC }}$ is the emission of anthropogenic $\mathrm{CO}_{2}$ and the inherent isotopic decline in the atmosphere over the last 150 years (Suess effect). The bias toward lighter $\delta^{13} \mathrm{C}_{\text {DIC }}$ in surface Arctic waters relative to deep waters, which are not affected by the Suess effect due to longer residence times, has been estimated from a comparison of water column and sediment surface data as $\sim-1 \%$ in the 1990s $[7,28]$ or somewhat smaller as $\sim-0.7 \%$ from model estimates (A. Schmittner pers. com., 2014). Here, we present data of $\delta^{13} \mathrm{C}_{\mathrm{DIC}}$ in the water column in the Eurasian and Amerasian basins of the Arctic Ocean from oceanographic summer expeditions taken between 1991 and 2008. In the upper $200 \mathrm{~m}$, the residence time is within about 20 years [49], in the same range as the sampling period of our dataset. The $\delta^{13} \mathrm{C}$ change in the atmosphere during this period was about $0.5 \%$, with $\sim-8$ and $-8.5 \%$ in 1990 and 2010, respectively (based on NOAA ESRL GMD monthly data measured at Barrow, Alaska available at http://www.esrl.noaa.gov/gmd/). The difference in oceanic $\delta^{13} \mathrm{C}_{\text {DIC }}$ is usually smaller compared to the atmosphere and considering the sampling time and upper water residence time may, therefore, be as large as $0.5 \%$ between the datasets and potentially also within the water column. With this potential bias in mind, our data can serve as a baseline for future investigations of changes to be expected with the progression of climate change. Such a baseline is also important for the interpretation of paleo-records from the Arctic region that is widely recognized in its importance for comprehending global paleoclimate processes (e.g., [37]. Beyond a description of $\delta^{13} \mathrm{C}_{\text {DIC }}$ distribution in the Arctic Ocean, we evaluate the connection of the observed features with biological and transport processes within the Arctic Ocean as well as potential $\delta^{13} \mathrm{C}_{\text {DIC }}$ sources such as low- $\delta^{13} \mathrm{C}_{\text {DIC }}$ river water $[2,12,20]$. With the profound impact of climate change on sea ice and brine formation, we specifically address the question, whether sea-ice related processes also affect the distribution of $\delta^{13} \mathrm{C}_{\mathrm{DIC}}$ in the Arctic Ocean.

\section{Data and methods}

Samples were taken on various expeditions between 1991 and 2008 (Fig. 1) and are from published as well as previously unpublished data presented here as part of this study (Table 1). Precision for $\delta^{13} \mathrm{C}_{\mathrm{DIC}}$ ranges from \pm 0.02 to $\pm 0.23 \%$ and is partly not known. Two entire datasets were excluded due to (1) little variation and consistently too low values within deep waters compared to all other datasets and (2) little variation and extremely low values within the upper $500 \mathrm{~m}$ that show no relation to variations in nutrient levels. We interpret these circumstances as signs for consistent atmospheric contamination probably acquired during inadequate handling of samples, e.g., bubbleling during sampling procedure.

\section{Calculation of river water and sea-ice meltwater contained within the water column}

Marine water masses and freshwater fractions in each water sample are estimated using mass balance calculations based on $\delta^{18} \mathrm{O}$ and salinity (e.g., [6, 18, 32, 34, 52]). To distinguish also between Atlantic- and Pacific-derived waters, the ratios of nutrients with different nitrate to phosphate ratios (N/P) may be used [26]. It is assumed that each summer sample is a mixture between Atlantic-derived water $\left(f_{m a r}\right)$, Pacific-derived water $\left(f_{p}\right)$, river runoff $\left(f_{r}\right)$, and sea-ice meltwater $\left(f_{S I M}\right)$. Technically $f_{r}$ refers to meteoric water, but as river runoff dominates in the Arctic Ocean we refer to runoff for simplicity. For further details on calculations and the selection of end members, refer to [9]. As N and/or P data needed for this analysis are not available at a number of stations, we also used a reduced 3-component calculation that assumes marine water to be Atlanticderived water only and ignores Pacific-derived waters [6]. This approach may be safely applied, and is even more 
Fig. 1 a Index map with location of datasets. The different datasets are indicated by color coding. Single stations are highlighted by additional symbols as used in Figs. 4 and 5. Below b sections of $\delta^{13} \mathrm{C}_{\text {DIC }}$ and $\delta^{13} \mathrm{C}_{\text {as }}$ of the upper $500 \mathrm{~m}$. For an overview, all station data were projected to the $0 \% 180^{\circ}$ meridian running from Fram Strait to the Chukchi Sea shelf

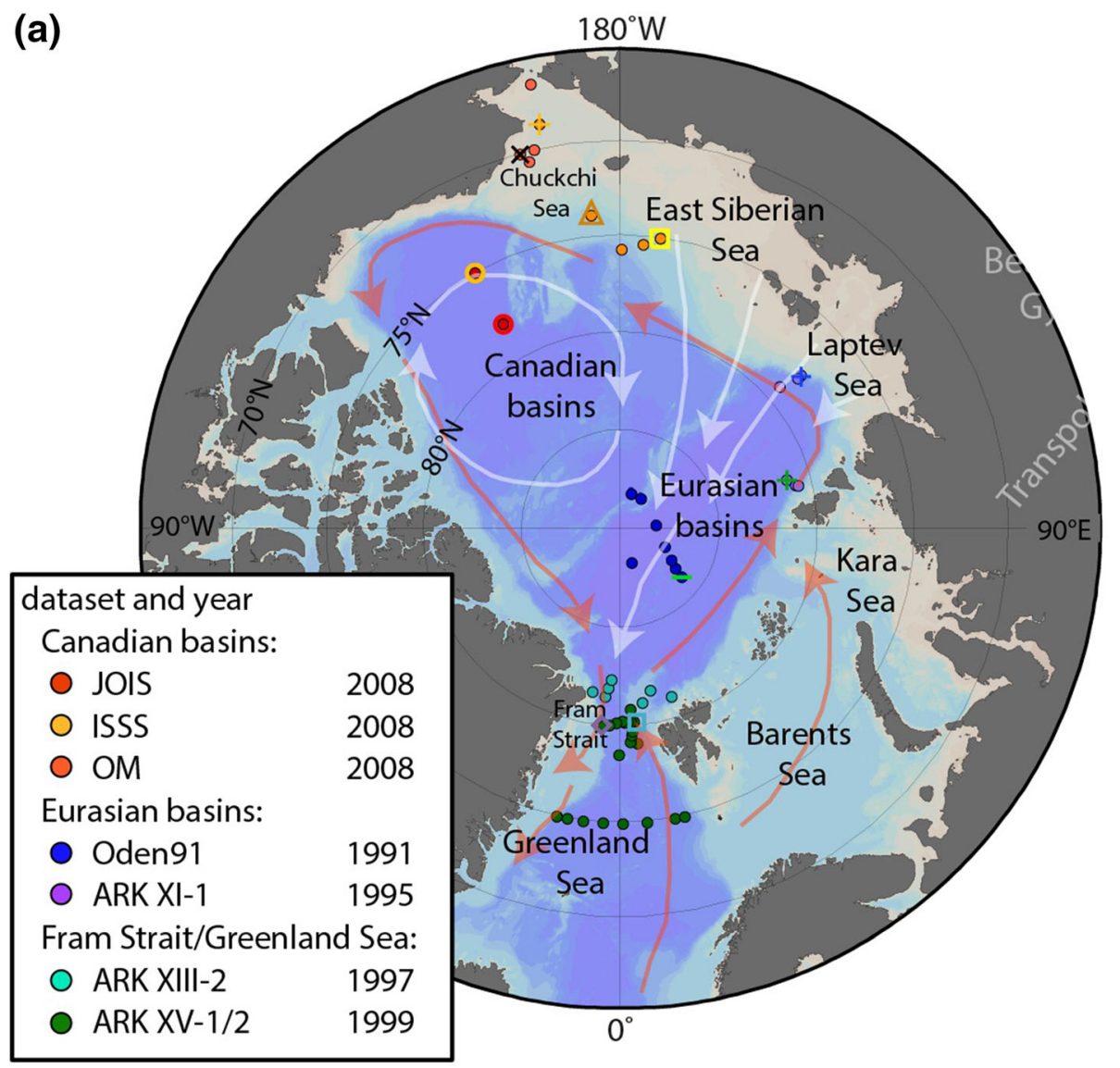

(b)

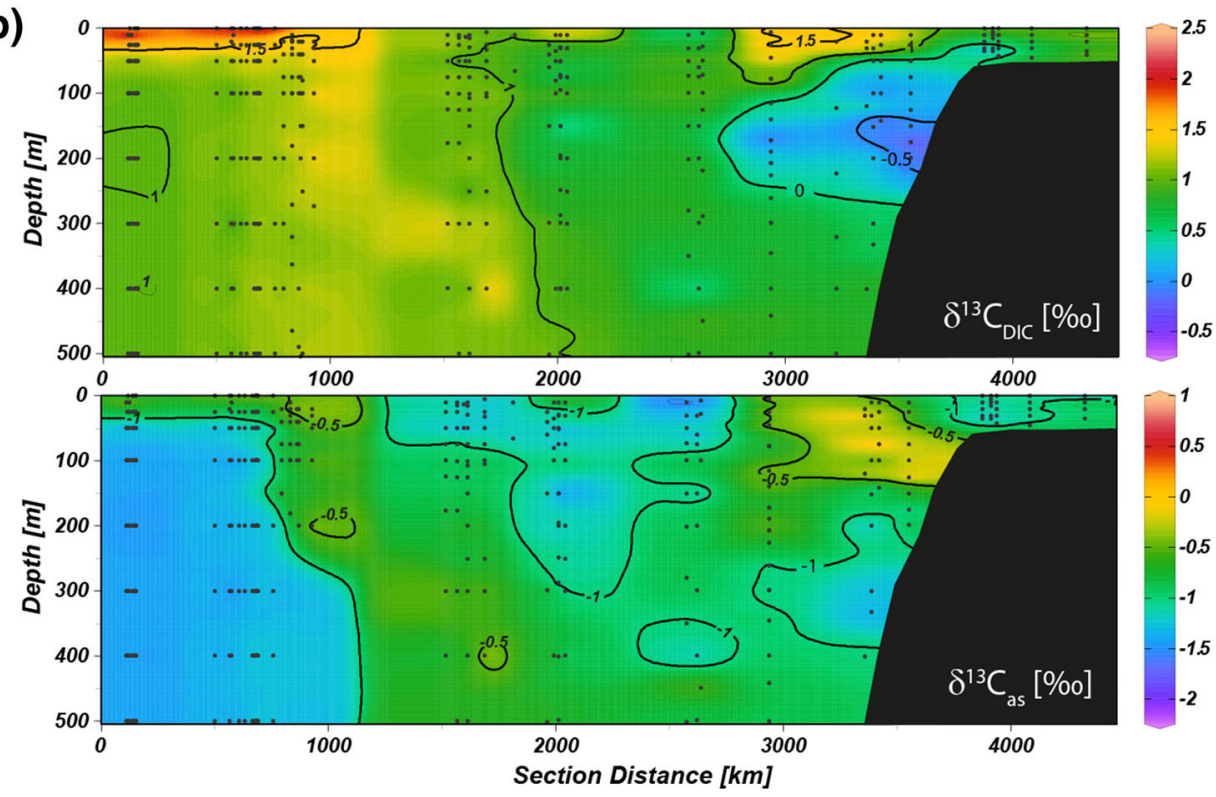

suitable in areas where Pacific-derived waters are absent such as in most parts of the Eurasian Basin. But in areas where Pacific-derived waters are present, such as in the Canada Basin, a 3-component approach considerably overestimates the river water component. Fractions of seaice meltwater (SIM), on the other hand, are nearly unaffected by different approaches [9]. Therefore, river water fractions were only calculated with the 4-component approach, while SIM fractions were calculated with the 3-component approach allowing for wider data coverage. All fractions are net values in each sample, and reflect the time-integrated effects (i.e., of SIM) on the sample volume over the residence time of the water. Negative SIM fractions $\left(f_{\text {SIM }}\right)$ reflect the amount of water removed by sea-ice 
Table 1 List of presented $\delta^{13} \mathrm{C}_{\text {DIC }}$ datasets

\begin{tabular}{|c|c|c|c|c|c|}
\hline Expedition & Year & Area(s) & Notes & $\begin{array}{l}\text { Precision } \\
(\%)\end{array}$ & $\begin{array}{l}\text { Further } \\
\text { parameters }\end{array}$ \\
\hline Oden91 & $\begin{array}{l}\text { Sep.-Oct. } \\
1991\end{array}$ & Eurasian Basin & $\begin{array}{l}\text { Measured at Univ. Bergen (T. Johannessen pers. com. } \\
\text { 1997). }\end{array}$ & Not known & $\begin{array}{l}\delta^{18} \mathrm{O}, \mathrm{O}_{2}, \mathrm{~N}, \mathrm{P}, \\
\quad \mathrm{Si}\end{array}$ \\
\hline ARK XI-1 & Aug. 1995 & Eurasian Basin & Published data [48] & \pm 0.02 & $\begin{array}{l}\delta^{18} \mathrm{O}, \mathrm{O}_{2}, \mathrm{~N}, \mathrm{P} \\
\mathrm{Si}\end{array}$ \\
\hline ISSS-08 & Sep. 2008 & $\begin{array}{l}\text { North of East Siberian } \\
\text { Sea }\end{array}$ & $\begin{array}{l}\text { Measured at Univ. Florida (stable isotope mass } \\
\text { spectrometry facility) }\end{array}$ & \pm 0.06 & $\begin{array}{l}\delta^{18} \mathrm{O}, \mathrm{O}_{2}, \mathrm{~N}, \mathrm{P} \\
\quad \mathrm{Si}\end{array}$ \\
\hline $\begin{array}{l}\text { OM08 } \\
\text { "Oshoro } \\
\text { Maru" }\end{array}$ & July 2008 & Chukchi Sea & $\begin{array}{l}\text { Measured at Univ. Florida (stable isotope mass } \\
\text { spectrometry facility) }\end{array}$ & \pm 0.06 & $\begin{array}{l}\delta^{18} \mathrm{O}, \mathrm{O}_{2}, \mathrm{~N}, \mathrm{P}, \\
\quad \mathrm{Si}\end{array}$ \\
\hline JOIS 2008 & Aug. 2008 & Canada Basin & Published data [22] & \pm 0.23 & $\mathrm{O}_{2}, \mathrm{~N}, \mathrm{P}, \mathrm{Si}$ \\
\hline ARK XIII-2 & July 1997 & Fram Strait & Published data [48] & \pm 0.02 & $\begin{array}{l}\delta^{18} \mathrm{O}, \mathrm{O}_{2}, \mathrm{~N}, \mathrm{P}, \\
\quad \mathrm{Si}\end{array}$ \\
\hline ARK XV-1 & July 1999 & $\begin{array}{l}\text { Greenland Sea and Fram } \\
\text { Strait }\end{array}$ & Measured at Leibniz Laboratory Kiel (LLK; [19]) & \pm 0.02 & $\delta^{18} \mathrm{O}, \mathrm{O}_{2}, \mathrm{P}, \mathrm{Si}$ \\
\hline ARK XV-2 & July 1999 & Fram Strait & Measured at LLK & \pm 0.02 & $\delta^{18} \mathrm{O}, \mathrm{O}_{2}, \mathrm{P}, \mathrm{Si}$ \\
\hline
\end{tabular}

Given are names and abbreviations of expeditions used throughout the manuscript. Also listed are the available additional parameters $\delta^{18} \mathrm{O}$, dissolved oxygen $\left(\mathrm{O}_{2}\right)$ and nutrient concentrations: nitrate $(\mathrm{N})$, phosphate $(\mathrm{P})$ and silicate $(\mathrm{Si})$

formation and are proportional to the subsequent addition of brines to the water column. An uncertainty of \pm 0.3 to $1 \%$, resulting from analytical errors, associated with $\delta^{18} \mathrm{O}$ (0.05 and $0.15 \%$ for OM08), salinity and hydrochemical measurements, is estimated for each fraction [9]. An additional systematic error depends on the exact choice of end-member values. When end-member values are varied within the estimated uncertainties, both fractions are shifted by up to $\sim 1 \%$, but results are always qualitatively conserved, even when tested with extreme end-member variations (see [9]).

\section{Results}

The $\delta^{13} \mathrm{C}_{\mathrm{DIC}}$ data compiled from the Arctic Ocean have an overall range between about -0.6 to $+2.2 \%$ (Table 2 ). Deep waters are at $\sim 1$ to $1.5 \%$ in $\delta^{13} \mathrm{C}_{\mathrm{DIC}}$ within both basins (Fig. 2). The $\delta^{13} \mathrm{C}_{\mathrm{DIC}}$ within the upper layers of the

Table 2 Averages of $\delta^{13} \mathrm{C}_{\mathrm{DIC}}$ and $\delta^{13} \mathrm{C}_{\mathrm{as}}$ for stations within the deep basins: Eurasian Basin (EB), Makarov Basin (MB), and Canada Basin (CB)

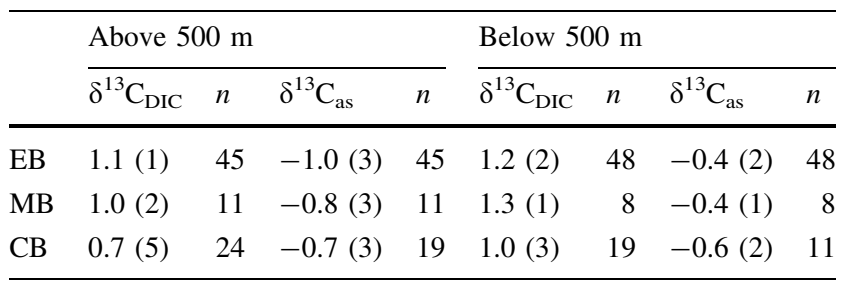

Given are the averages of all data points above $500 \mathrm{~m}$ water depth and below $500 \mathrm{~m}$ water depth. The standard deviations are given for the last digit in parenthesis. Also given is the number of measurements $n$
Eurasian Basin is $\sim 1 \%$ with a range of $0-1.5 \%$, and shows a relatively little variation compared to the Canada Basin. In Fram Strait and the adjacent Greenland Sea, $\delta^{13} \mathrm{C}_{\text {DIC }}$ is predominantly above $1 \%$ and as high as $2.5 \%$ in the upper $\sim 30 \mathrm{~m}$ (Fig. 2b). In the Canada Basin, $\delta^{13} \mathrm{C}_{\mathrm{DIC}}$ values range between -0.6 and $2 \%$ in the upper 200-250 $\mathrm{m}$ with strong regional differences (Fig. 2b). Within low-salinity surface waters, $\delta^{13} \mathrm{C}_{\mathrm{DIC}}$ reaches up to $\sim 2 \%$ at salinities around 29-30 (Fig. 3). At higher salinities, $\delta^{13} \mathrm{C}_{\mathrm{DIC}}$ values decline to $\sim 0 \%$ within the Upper Halocline Waters (UHW) at $\sim 33.1$ salinity and to $\sim-0.5 \%$ within the Lower Halocline Waters (LHW) between $\sim 34$ and 34.5 salinity (Table 3 ). In the Atlantic layer below $\sim 200 \mathrm{~m}, \delta^{13} \mathrm{C}_{\text {DIC }}$ values are consistently between $\sim 1$ and $1.5 \%$ throughout the Arctic Ocean.

\section{Discussion}

The broad Siberian Arctic shelf regions are areas of high biological productivity (e.g., $[15,25,35,41])$. Therefore, it is not surprising to find high $\delta^{13} \mathrm{C}_{\mathrm{DIC}}$ within the shallow subsurface layer, where light $\delta^{13} \mathrm{C}$ is incorporated into organic material, and lower $\delta^{13} \mathrm{C}_{\mathrm{DIC}}$ values in the deeper layers of the halocline, where organic material is re-mineralized. This pattern, typical for productivity and decay of organic material, is clearly seen in $\delta^{13} \mathrm{C}_{\mathrm{DIC}}$ profiles from the Canada Basin, where low $\delta^{13} \mathrm{C}_{\text {DIC }}$ values are found between $\sim 150$ and $250 \mathrm{~m}$ (Fig. $4 \mathrm{a}$ ) and $\sim 33$ to $\sim 34.5$ salinity within UHW and LHW, while relatively higher values are seen near the surface (Fig. 5a). Low $\delta^{13} C_{\text {DIC }}$ values within the halocline layers are also found at the 


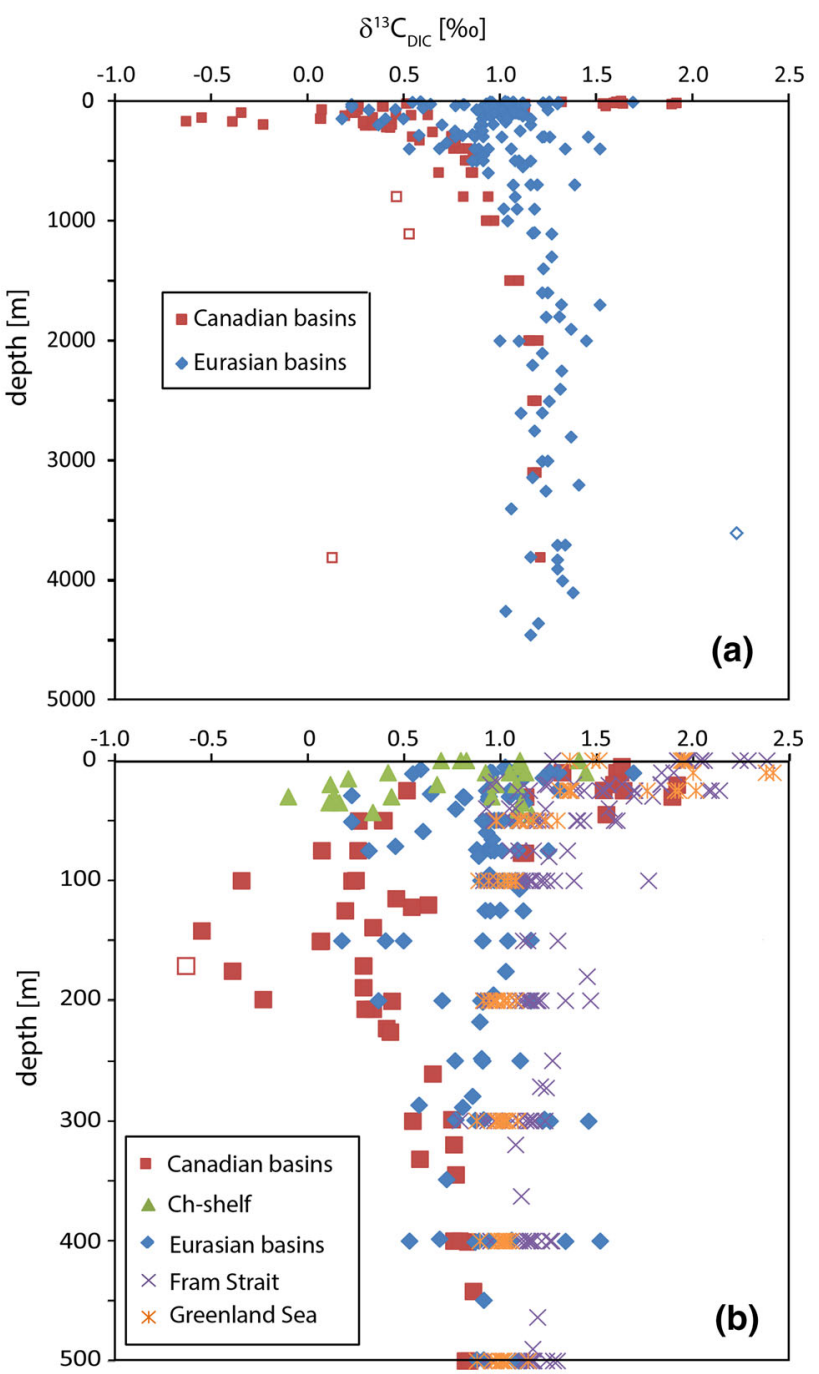

Fig. 2 Profiles of $\delta^{13} \mathrm{C}_{\text {DIC }}$ for the Eurasian and Canada basins of the Arctic Ocean. a Data for the entire water column. b Data for the upper $500 \mathrm{~m}$ of the water column. For the Fram Strait and Greenland Sea areas, only data from upper water column are available. Outliers are shown with open symbols

continental slope of the East Siberian Sea and, to a smaller extent, at the Laptev Sea slope (Figs. 4a, 5a). This distribution suggests that the low $\delta^{13} \mathrm{C}_{\mathrm{DIC}}$ values in the Amerasian Basin may originate from the shelves of the Chukchi, East Siberian, and Laptev seas. We hypothesize that low $\delta^{13} \mathrm{C}_{\mathrm{DIC}}$ signals from the Siberian shelves may propagate with the boundary current that transports halocline waters from west to east along the Eurasian continental margin [1, $11,31]$. Surprisingly, the $\delta^{13} \mathrm{C}_{\mathrm{DIC}}$ pattern related to organic matter cycling appears to be nearly absent in the Eurasian Basin, which poses the question, whether local productivity and decay of low- $\delta^{13} \mathrm{C}$ organic material are indeed so different between the Arctic basins? Alternatively, this dissimilarity may be controlled by different circulation patterns in the Canadian and Eurasian basins.

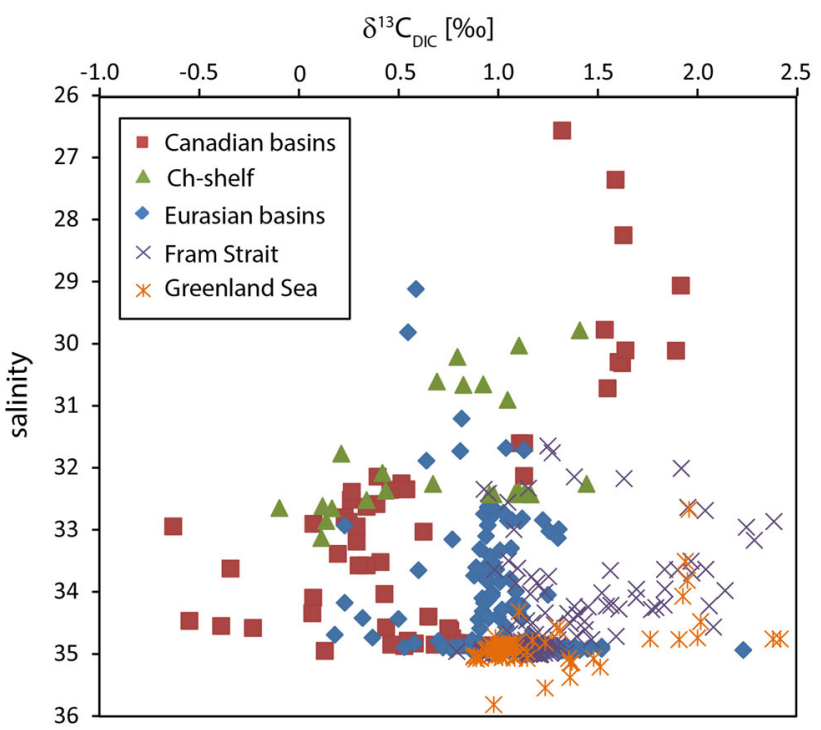

Fig. $3 \delta^{13} \mathrm{C}_{\text {DIC }}$ versus salinity for the upper $500 \mathrm{~m}$ of the water column in the Eurasian and Canada basins as well as the Fram Strait and Greenland Sea. Note the inverted scale for salinity

Table 3 Averages of $\delta^{13} \mathrm{C}_{\mathrm{DIC}}$ and $\delta^{13} \mathrm{C}_{\mathrm{as}}$ for stations within the deep basins or north of the shelf break (all datasets except OM08 from the Chukchi Sea shelf)

\begin{tabular}{lllll}
\hline Layer & $\delta^{13} \mathrm{C}_{\text {DIC }}$ & $n$ & $\delta^{13} \mathrm{C}_{\text {as }}$ & $n$ \\
\hline Surface & $1.0(4)$ & 55 & $-0.9(5)$ & 52 \\
UHW & $0.2(3)$ & 13 & $-0.3(4)$ & 12 \\
LHW & $0.8(4)$ & 44 & $-1.0(3)$ & 40 \\
AW & $1.0(2)$ & 59 & $-0.8(3)$ & 55 \\
DW & $1.2(3)$ & 56 & $-0.4(2)$ & 50 \\
\hline
\end{tabular}

Given are the averages within the surface waters, Upper Halocline Water (UHW), Lower Halocline Water (LHW), Atlantic Water down to $1000 \mathrm{~m}(\mathrm{AW})$ and Deep Water below $1000 \mathrm{~m}$ (DW) water depth. The standard deviations are given for the last digit in parenthesis. Also given is the number of measurements $n$

In the following discussion, we will investigate what factors cause the low $\delta^{13} \mathrm{C}_{\mathrm{DIC}}$ values in the Canada Basin and the difference in $\delta^{13} \mathrm{C}_{\text {DIC }}$ patterns between the Eurasian and the Canada basins. We will evaluate the impact to biological productivity on $\delta^{13} \mathrm{C}_{\mathrm{DIC}}$ within the two basins and analyze the non-biological factors. We will also review the Arctic Ocean halocline circulation in relation to $\delta^{13} \mathrm{C}_{\text {DIC }}$ and analyze the influence of low $\delta^{13} \mathrm{C}_{\mathrm{DIC}}$ in river water as well as the potential effect of sea-ice melt and formation.

\section{Biotic and non-biotic influences on $\delta^{13} C_{\text {DIC }}$ in the Arctic Ocean}

To distinguish the influence of biological and non-biotic factors, $\delta^{13} \mathrm{C}_{\text {DIC }}$ data can be adjusted by their nutrient levels. Phosphate- and nitrate-based adjustments have been 


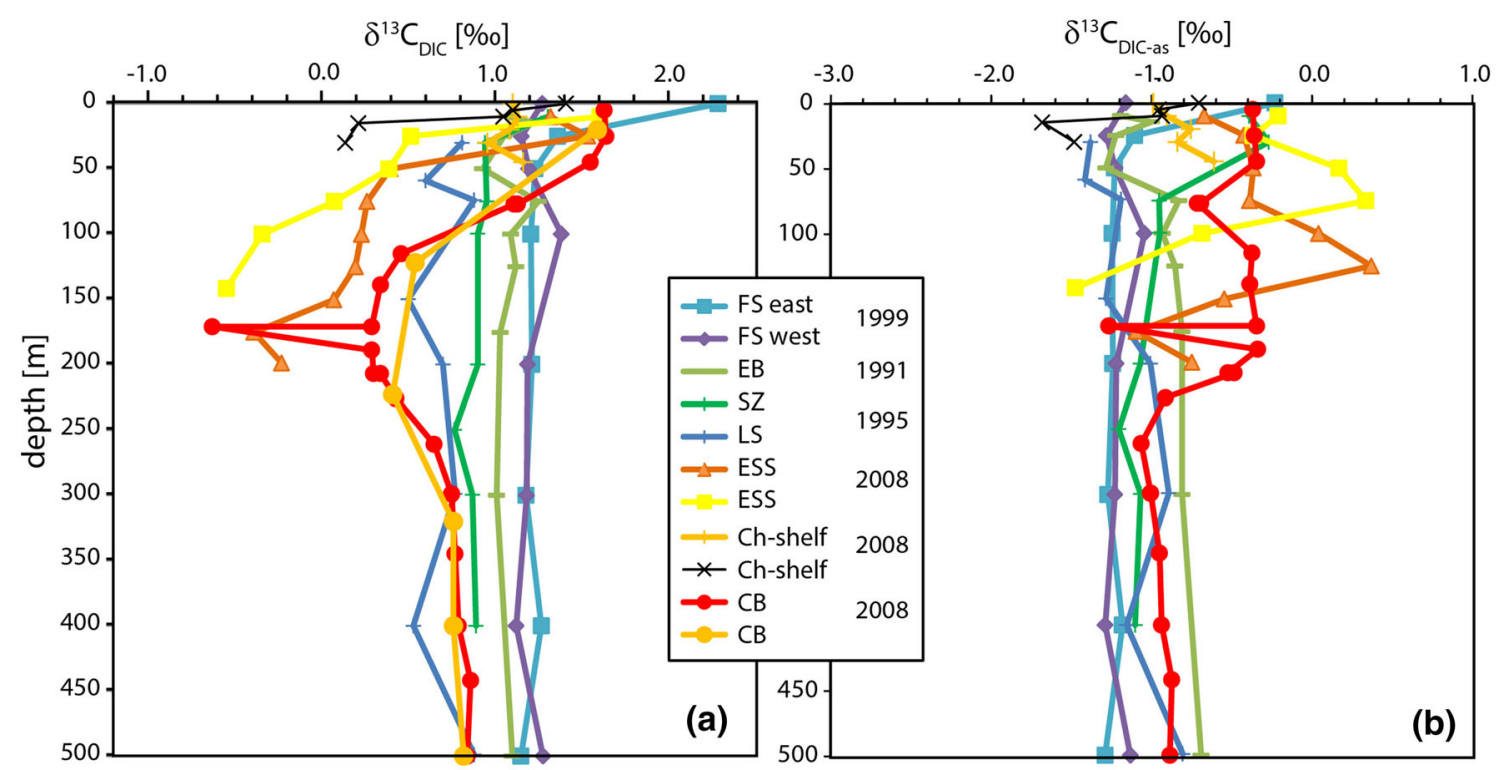

Fig. 4 Depth profiles of $\delta^{13} \mathrm{C}_{\mathrm{DIC}}$ and $\delta^{13} \mathrm{C}_{\text {DIC-as }}$ for the upper $500 \mathrm{~m}$ of the water column. The single light value at $175 \mathrm{~m}$ in the Canada Basin (open red dot) is considered to be an outlier. Detailed station locations are shown in Fig. 1 with corresponding symbols

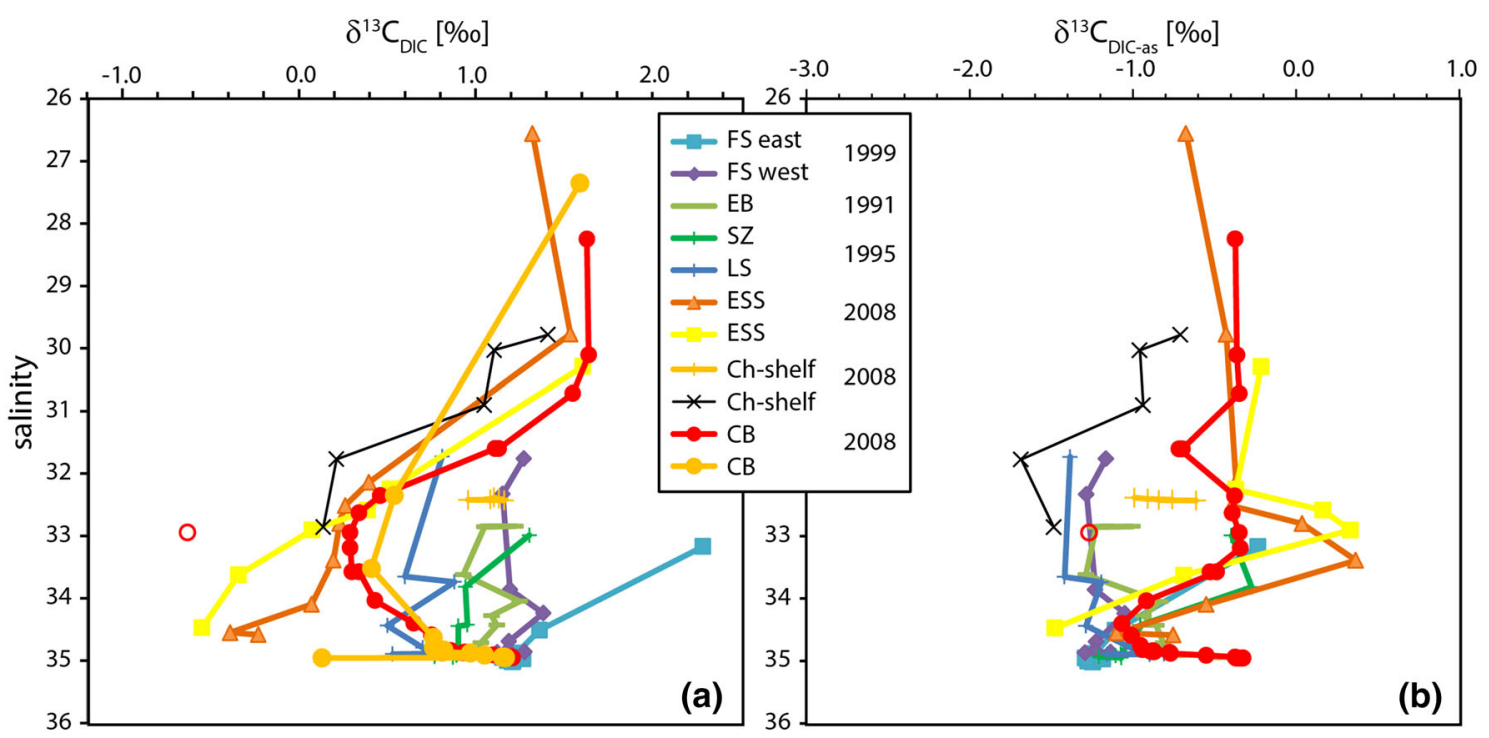

Fig. 5 Relation of $\delta^{13} \mathrm{C}_{\mathrm{DIC}}$ and $\delta^{13} \mathrm{C}_{\mathrm{DIC}-\mathrm{as}}$ versus salinity. Note the inverted scale for salinity. The single light value at 33 salinity in the Canada Basin (open red dot) is considered to be an outlier. Detailed station locations are shown in Fig. 1 with corresponding symbols

applied by [27] and by [33], respectively. Adjusted $\delta^{13} \mathrm{C}_{\text {DIC }}$ values are generally referred to as $\delta^{13} \mathrm{C}_{\text {as }}$ as all non-biotic factors are assumed to be caused by air-sea exchange processes. Calculation of $\delta^{13} \mathrm{C}_{\mathrm{as}}$ may be based on:

1. $\delta^{13} \mathrm{C}_{\mathrm{as}}=\delta^{13} \mathrm{C}_{\mathrm{DIC}}-\left(2.7-1.1 * \mathrm{PO}_{4}\right)$ after [27]

2. $\delta^{13} \mathrm{C}_{\mathrm{as}}=\delta^{13} \mathrm{C}_{\mathrm{DIC}}-\left(2.2-0.06 * \mathrm{NO}_{3}\right)$ after [33]

Both these globally calibrated equations predict the $\delta^{13} \mathrm{C}_{\text {DIC }}$ due to the biological activity from the measured nutrient concentrations and subtract the calculated value from the measured $\delta^{13} \mathrm{C}_{\text {DIC. }}$. For the relation between $\delta^{13} \mathrm{C}_{\text {DIC }}$ and nutrients, ideal biological processes with constant fractionation and constant Redfield nutrient ratios are assumed based on global or regional averages. Clearly, both corrections are not adjusted to local Arctic conditions, where, e.g., Pacific- and Atlantic-derived waters have different preformed nutrient levels. In our data from the Canada Basin and adjacent shelves, high nutrient levels are mostly related to low $\delta^{13} \mathrm{C}_{\text {DIC }}$ from re-mineralized organic material, while low nutrient levels are related to high 
$\delta^{13} \mathrm{C}_{\text {DIC }}$ reflecting nutrients fixed in organic material (Fig. 6a and b). In contrast, in the Eurasian Basin, $\delta^{13} \mathrm{C}_{\text {DIC }}$ remains nearly constant, while the nitrate range is high (Fig. 6b) as biological fixation is probably limited by low phosphate levels (Fig. 6a). Atlantic-derived waters have relatively low P levels (Fig. 6c), which may limit biological production in the Eurasian Basin (Fig. 6a), while N levels remain relatively high (Fig. 6b; see blue diamond for Eurasian Basin waters). Pacific-derived waters have on average higher $\mathrm{P}$ (Fig. 6c), but both $\mathrm{N}$ and $\mathrm{P}$ levels are low for $\delta^{13} \mathrm{C}_{\text {DIC }}$ values that are high, which reflect the fixation of carbon from the DIC pool in low- $\delta^{13} \mathrm{C}$ organic matter (Fig. 6a, b; see green triangles for Chukchi Sea and part of Canada Basin data shown by red squares). Due to the phosphate limitation in the Eurasian part of the Arctic
Ocean, we have adjusted the $\delta^{13} \mathrm{C}_{\mathrm{DIC}}$ data for biological processes applying the phosphate-based correction [27], an approach that also allows us to analyze more of the $\delta^{13} \mathrm{C}_{\mathrm{DIC}}$ data due to the greater availability of phosphate measurements in our dataset. This result differs from the observations off Oregon, were [33] observed evidence for $\mathrm{N}$-limitation. We will use the term $\delta^{13} \mathrm{C}_{\mathrm{as}}$ for the adjusted $\delta^{13} \mathrm{C}_{\text {DIC }}$ data, although this notation implies that all nonbiotic factors are related to air-sea exchange, which is not strictly correct as river water and sea-ice processes may also have an impact.

In the southern Eurasian Basin and in Fram Strait, $\delta^{13} \mathrm{C}_{\mathrm{as}}$ is relatively constant with values close to $-1 \%$ (Figs. $4 \mathrm{~b}$, 5b) similar to North Atlantic values [27]. But in the Canada Basin and at the East Siberian and Chukchi slopes, $\delta^{13} \mathrm{C}_{\mathrm{as}}$
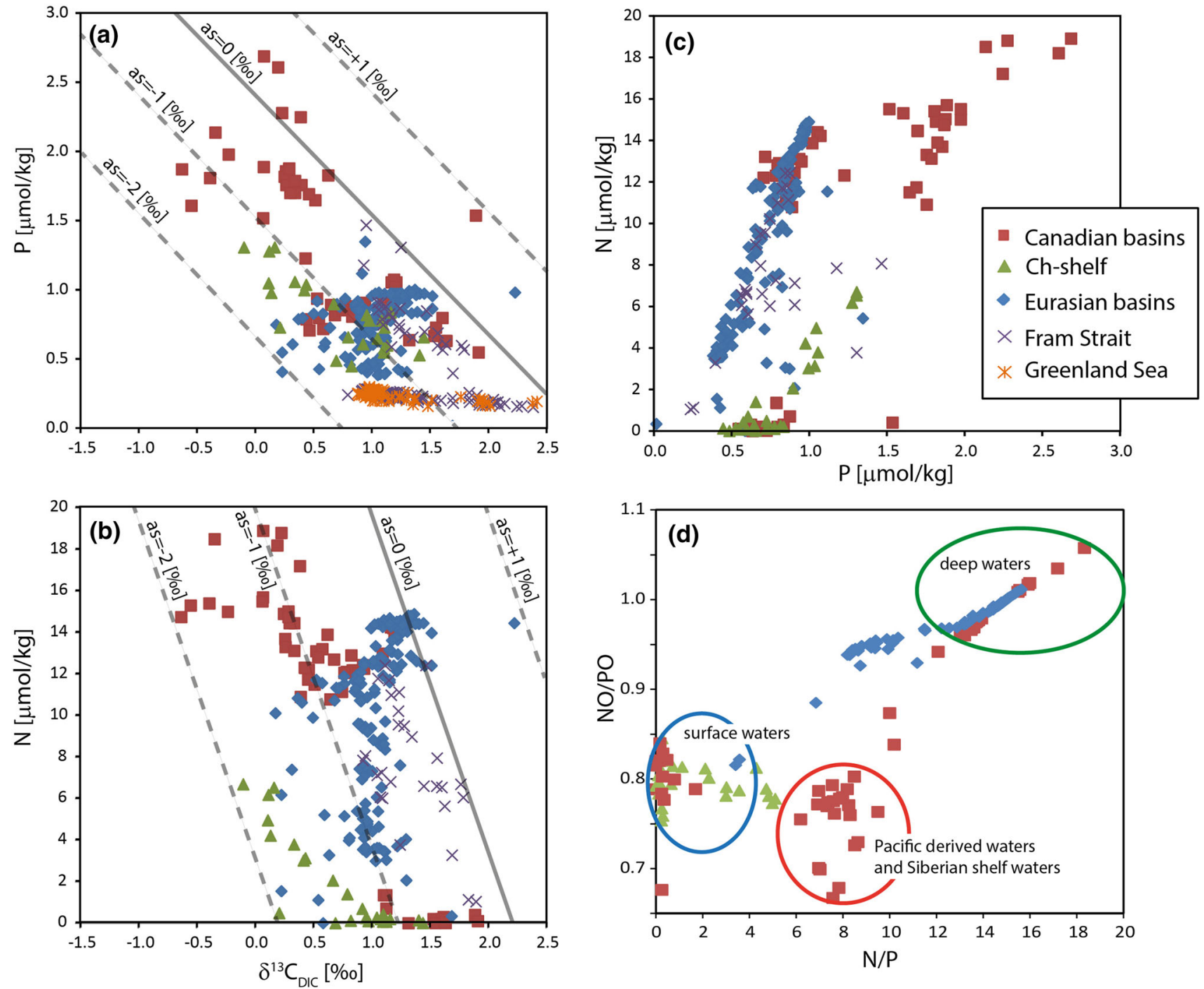

Fig. 6 Relation between $\delta^{13} \mathrm{C}_{\mathrm{DIC}}$ and a dissolved phosphate $(\mathrm{P})$ and b nitrates $(\mathrm{N})$. Indicated are lines of constant air-sea exchange according to equations given within text for phosphate- and nitrate-

based adjustments. Also shown are the relation between $\mathbf{c} \mathrm{N}$ and $\mathrm{P}$ and d the ratios NO/PO versus N/P. For further explanation, see text 
values show a considerable variation and internal structure within the water column (Figs. 4b, 5b). In the upper $200 \mathrm{~m}$ in the Canada Basin and at 100-150 m at the ESS slope, $\delta^{13} \mathrm{C}_{\mathrm{as}}$ is relatively high, between -0.5 and $0.5 \%$ (see yellow, orange and red profiles in Fig. 4b). Under equilibrium conditions, invading atmospheric $\mathrm{CO}_{2}$ at cold temperatures increases the $\delta^{13} \mathrm{C}_{\mathrm{DIC}}$ and thus leads to relatively high $\delta^{13} \mathrm{C}_{\mathrm{as}}$ values [30]. But because the equilibration time between the atmosphere and even a shallow water column is relatively long, there are immediate impacts that lower or increase $\delta^{13} \mathrm{C}_{\text {DIC }}$ when $\mathrm{CO}_{2}$ enters or leaves the DIC pool, respectively [27] and thus act initially into opposite direction than equilibrium processes. While chemical equilibrium occurs on timescales of about 1 year, isotopic equilibration takes on the order of 10 years or more for a shallow water column of $\sim 50 \mathrm{~m}$ (see model calculation in [27]). As the surface residence time in the Arctic is well below 10 years and considerably shorter on the Arctic shelves [42], it may be concluded that air-sea processes are far from equilibrium within the entire Arctic Ocean and shelf regions and that invading atmospheric $\mathrm{CO}_{2}$ will lower $\delta^{13} \mathrm{C}_{\mathrm{DIC}}$ and $\delta^{13} \mathrm{C}_{\mathrm{as}}$ values. Nevertheless, part of the $\delta^{13} \mathrm{C}_{\mathrm{as}}$ variability may also be connected to variations in surface residence time and thus variations in incomplete isotopic equilibration. Therefore, the observed relatively high $\delta^{13} \mathrm{C}_{\text {as }}$ values may indicate that the invasion of isotopically light atmospheric $\mathrm{CO}_{2}$ in the upper Canada Basin waters is weaker than in the North Atlantic and Eurasian Basin, which likely arises from the inhibition of air-sea gas equilibration due to the more complete ice coverage in the Canada basin. Considerably, lighter $\delta^{13} \mathrm{C}_{\mathrm{as}}$ values of $\sim-1.5 \%$ are found at $\sim 150 \mathrm{~m}$ water depth or bottom depth at the continental slope of the ESS and on the Chukchi shelf (Fig. 4b). These light $\delta^{13} \mathrm{C}_{\mathrm{as}}$ values potentially indicate enhanced invasion of light atmospheric $\mathrm{CO}_{2}$, likely associated with sinking of near surface water during winter cooling or brine rejection during sea-ice formation.

As an alternative, part of the observed structure in $\delta^{13} \mathrm{C}_{\mathrm{as}}$ within the water column might be caused by regional deviations in rates of biological processes relative to the global $\delta^{13} \mathrm{C}-\mathrm{P}$ relationship. For example, $\delta^{13} \mathrm{C}$ fractionation may be higher than the assumed global averages in high productivity areas at low temperatures [27]. Therefore, the $\delta^{13} \mathrm{C}_{\mathrm{as}}$ values may be locally underestimated or overestimated, by the global relationship because the organic matter is formed or remineralized, respectively, with regionally varying biological processes. If that were the case, the relatively high $\delta^{13} \mathrm{C}_{\mathrm{as}}$ in the upper $200 \mathrm{~m}$ of the Canada Basin and at 100-150 $\mathrm{m}$ at the ESS slope in comparison to the North Atlantic values may be caused by an underestimation of ${ }^{13} \mathrm{C}$ fractionation during the production of organic matter or its respiration. Accordingly, low $\delta^{13} \mathrm{C}_{\mathrm{as}}$ may partly result from an underestimation due to remineralization of organic matter with lower than average $\delta^{13} \mathrm{C}$ composition. A comparison of production between different regions is difficult but nonRedfield productivity may be estimated [17]. Away from the sea surface, the quasi-conservative tracers $\mathrm{NO}$ and $\mathrm{PO}$ $\left(\mathrm{NO}=9 *\left[\mathrm{NO}_{3}{ }^{-}\right]+\mathrm{O}_{2}\right.$ and $\left.\mathrm{PO}=135^{*}\left[\mathrm{PO}_{4}{ }^{-}\right]+\mathrm{O}_{2} ;[14]\right)$ account for the approximate stoichiometric ratios of nutrient and oxygen during consumption and production or regeneration. A plot of NO/PO versus $\mathrm{N} / \mathrm{P}$ can provide an indication of differences in nutrient consumption or regeneration that deviates from Redfield ratios [17]. In the Arctic, variations in non-Redfield productivity can be seen between surface waters and halocline layers in comparison to deep waters within our datasets (Fig. 6d). No relationship between either the N/P ratio or the NO/PO preformed nutrient ratio to variations in $\delta^{13} \mathrm{C}_{\mathrm{DIC}}$ values is apparent (not shown). While relatively low NO/PO ratios within Pacific-derived waters indicate an enlarged $\mathrm{N}$ loss relative to $\mathrm{P}$ with slower $\mathrm{N}$ recycling relative to $\mathrm{P}$ [17], surface waters from the Eurasian Basin and all other locations show the opposite effect with high NO/PO relative to N/P ratios (Fig. 6d). Therefore, in addition to differences in fractionation due to different productivity also different non-Redfield behavior may influence our estimates of $\delta^{13} \mathrm{C}_{\mathrm{as}}$. With this caveats in mind, the high $\delta^{13} \mathrm{C}_{\mathrm{as}}$ in the Canada Basin and low $\delta^{13} \mathrm{C}_{\text {as }}$ at the continental slope of the ESS and on the Chukchi shelf do suggest a possibility of reduced and enhanced air-sea exchange, respectively.

While a large part of the East Siberian Sea is overall an area of $\mathrm{CO}_{2}$ outgassing due to an excess of $\mathrm{pCO}_{2}$ derived from the degradation of organic carbon [2], the eastern part of the East Siberian Sea and the Chukchi Sea is a sink of $\mathrm{CO}_{2}$, especially at the end of the ice-free season $[4,36,44]$. This further confirms the notion that low $\delta^{13} \mathrm{C}_{\mathrm{as}}$ values in these areas likely reflect the invasion of isotopically light atmospheric $\mathrm{CO}_{2}$ under non-equilibrium conditions on the shelf areas.

The distribution of elevated $\delta^{13} \mathrm{C}_{\mathrm{as}}$ values of about $0.5 \%$ at $\sim 32.5$ to 34 salinity near the East Siberian Slope, on the Chukchi shelf and in the Canada Basin (Fig. 5) supports our hypothesis that high and low $\delta^{13} \mathrm{C}_{\mathrm{as}}$ signals may originate from common water masses transported along the Eurasian continental slope and into the Canada Basin.

\section{Oceanographic differences within the Arctic circulation with respect to $\delta^{13} C_{\text {DIC }}$}

Shelf waters in the Eurasian Basin are thought to recirculate in the Gakkel Gyre [23]. This concept is supported by a $\mathrm{Ra} / \mathrm{Th}$ estimate of shelf water residence ages of at least 8 years, which is much older than $\sim 3$ years for waters in the Transpolar Drift over the Lomonosov Ridge [39]. This 
considerably longer residence time of shelf waters may be a factor for the missing variability in $\delta^{13} \mathrm{C}_{\text {DIC }}$ in the Eurasian Basin due to a stronger degradation of any shelfsourced biological signal in this region.

Halocline waters in the Eurasian Basin are mainly LHW, with a relatively high salinity of $\sim 34.5$, which are formed by the modification of Atlantic waters over the Barents and northern Kara seas [38]. The southern part of the Eurasian Basin is mainly influenced by Atlanticderived waters, with only minor contributions from rivers. Waters from the large Siberian rivers, including the $\mathrm{Ob}$ and the Yenisey rivers, are carried eastward in the southern Kara Sea, but cross the shelf break only in the eastern Laptev Sea and the East Siberian Sea [9, 11]. Shelf waters with a considerable contribution from these rivers as well as sea-ice related brines then spread further eastward within the boundary current $[1,11,31]$ into the Canada Basin or along the Lomonosov Ridge in the Transpolar Drift [10]. Due to these low-salinity contributions, halocline waters in the Canada Basin are much fresher than in the Eurasian Basin and UHW is found at $\sim 33.1$ and is also strongly influenced by Pacific water with high silicate and generally higher nutrient levels (e.g., [3, 10]).

According to the upper ocean circulation, the low $\delta^{13} \mathrm{C}_{\text {DIC }}$ and high $\delta^{13} \mathrm{C}_{\mathrm{as}}$ values in the Canada Basin may not be of local origin, but may fully or partly originate from the continental margin in the upper water column. Such a transport of light $\delta^{13} \mathrm{C}_{\text {DIC }}$ signals is consistent with light $\delta^{13} C_{\text {DIC }}$ values and high $\delta^{13} C_{a s}$ in the bottom waters of the Chukchi shelf (Fig. 4a, black and yellow crosses) and at the upper slope of the East Siberian Sea at 100-200 m water depth (Fig. 4a, yellow squares and brown triangles). Stations at the central Laptev Sea slope show a similar pattern, although with a smaller $\delta^{13} \mathrm{C}_{\text {DIC }}$ depletion of $0.2 \%$ within the water column (Fig. 4a, blue crosses). Still the depletion is clearly visible relative to $\delta^{13} \mathrm{C}_{\text {DIC }}$ values in the Eurasian Basin, which are higher on average by $0.5 \%$ (Fig. 4a, green bars). Due to the Suess effect, an anthropogenic-induced bias of up to $\sim 0.5 \%$ between the upper layers and the observed depletion at $\sim 100-200 \mathrm{~m}$ water depth may be possible. Therefore, the observed depletion within the Eurasian Basin stations might be solely due to the anthropogenic effect but cannot explain the depletions at the slope of the East Siberian Sea. Overall, this distribution indicates an accumulation of light $\delta^{13} \mathrm{C}_{\mathrm{DIC}}$ and high $\delta^{13} \mathrm{C}_{\mathrm{as}}$ along the Siberian continental slope at $\sim 100-200 \mathrm{~m}$ water depth (Fig. 4) and $\sim 33$ to 33.5 salinity (Fig. 5), possibly in connection to Pacific-derived waters and the export of lowsalinity shelf water in the eastern part of the Laptev Sea and the East Siberian Sea [3, 10].

The pattern with high $\delta^{13} \mathrm{C}_{\text {DIC }}$ at the surface and low $\delta^{13} \mathrm{C}_{\text {DIC }}$ at an intermediate depth found in the Canada Basin is typical for biological processes. However, the $\delta^{13} \mathrm{C}_{\mathrm{as}}$ adjusted for biological effects still shows a similar structure (Fig. 4b) with relatively high $\delta^{13} \mathrm{C}_{\text {as }}$ values at about 32.5 to 34 salinity (Fig. 5b). This supports the assumption that both light $\delta^{13} \mathrm{C}_{\mathrm{DIC}}$ and high $\delta^{13} \mathrm{C}_{\mathrm{as}}$ values within the Canada Basin are transported in the Arctic Ocean halocline within the shelf-derived, eastward boundary current and may originate on the Laptev, East Siberian and Chukchi shelves and are thus partly influenced by Pacific-derived waters as well as Siberian shelf waters.

In contrast to the Canada Basin, $\delta^{13} \mathrm{C}_{\mathrm{DIC}}$ and $\delta^{13} \mathrm{C}_{\mathrm{as}}$ in the Eurasian Basin remain relatively constant. The stratification between the surface, LHW, and Atlantic waters in the southern Eurasian Basin is relatively weak compared to waters flowing off the Laptev, East Siberian and Chukchi shelves into the Canada Basin. We can speculate that $\mathrm{CO}_{2}$ invasion is much smaller for the Eurasian Basin and adjacent shelve regions or that the structure due to $\mathrm{CO}_{2}$ invasion is simply lost in the Eurasian Basin due to the reduced stratification on the Barents Sea and northern Kara Sea shelves in comparison to the shelf regions further eastwards.

\section{Influence of river $\delta^{13} C_{\text {DIC }}$ and brine enriched waters}

Siberian rivers have low $\delta^{13} \mathrm{C}_{\text {DIC }}$ values of about $-8.5 \%$ in the $\mathrm{Ob}$ and Yenisey rivers [20] and about $-8 \%$ in the Lena River $[2,12,20]$. Therefore, all water masses containing river water may potentially be influenced by low $\delta^{13} \mathrm{C}_{\text {DIC }}$ from this source. However, a comparison between $\delta^{13} \mathrm{C}_{\mathrm{DIC}}$ and the fraction of river water $\left(f_{r}\right)$, derived from the 4-component $\delta^{18} \mathrm{O}$ and salinity mass balance (see methods), shows little or slight positive correlation (Fig. 7). Marine waters have higher DIC concentrations compared to meteoric waters, e.g., in the Laptev Sea and, therefore, mixing and potential dilution of $\delta^{13} \mathrm{C}_{\mathrm{DIC}}$ signals are not linear [19]. As river runoff is an important nutrient source for biological processes in the otherwise nutrient-depleted Arctic, the $\delta^{13} \mathrm{C}_{\text {DIC }}$ values must be adjusted for biotic factors for a comparison with $\mathrm{f}_{\mathrm{r}}$. This comparison shows considerable scatter, but the individual datasets show slight trends toward lower $\delta^{13} \mathrm{C}_{\mathrm{as}}$ with increasing river influence (Fig. 7b). Shifts between and within datasets may be caused by strong variations in N/P consumption on the Siberian shelves that are reflected in strong variations in $\mathrm{N} / \mathrm{P}$ ratios [11]. The applied adjustment for the calculation of $\delta^{13} \mathrm{C}_{\mathrm{as}}$ may, therefore, only roughly remove the signal of biology in $\delta^{13} \mathrm{C}_{\mathrm{DIC}}$. However, the slight trend of $\delta^{13} \mathrm{C}_{\mathrm{as}}$ decrease with increasing river influence seen within some dataset suggests a minor but genuine remnant signal of low riverine $\delta^{13} \mathrm{C}_{\mathrm{DIC}}$ that is otherwise largely lost due to dilution. 


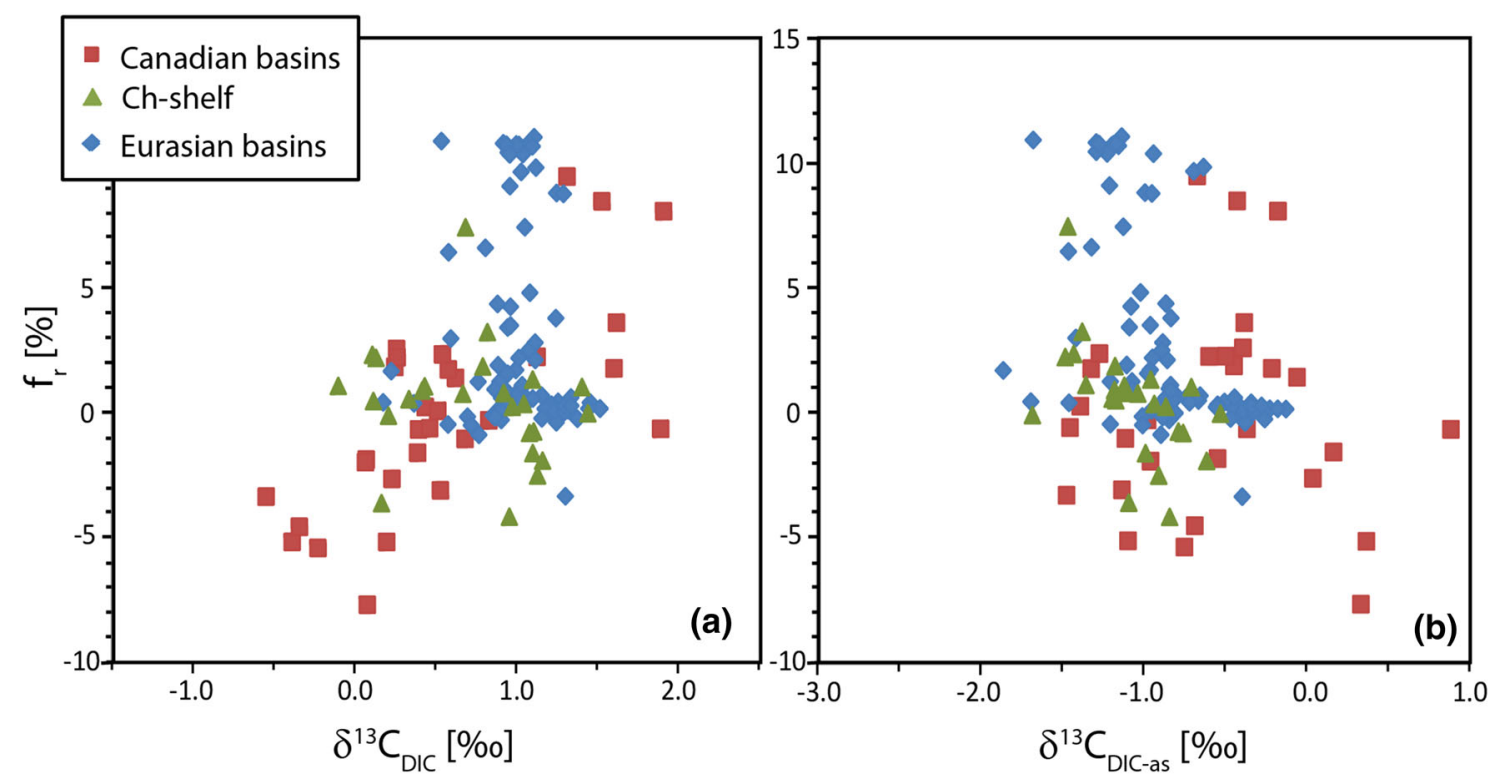

Fig. 7 Relation of $\delta^{13} \mathrm{C}_{\mathrm{DIC}}$ and $\delta^{13} \mathrm{C}_{\mathrm{DIC}-\text { as }}$ versus river fraction (fr; calculated with 4-component approach)

In addition to runoff, the shallow halocline carries a considerable fraction of shelf waters with brines introduced by sea-ice formation [9]. The signal from melting of seaice may also be transported in the upper halocline, but is usually found at the very surface in the upper $10-20 \mathrm{~m}$ of the water column only. We compare $\delta^{13} \mathrm{C}_{\mathrm{DIC}}$ and $\delta^{13} \mathrm{C}_{\mathrm{as}}$ with the fraction of sea-ice meltwater $\left(f_{S I M}\right)$, where positive and negative $\mathrm{f}_{\mathrm{SIM}}$ values correspond to the actual sea-ice melt and sea-ice related brines, respectively (see methods) (Fig. 8). Overall, a weak trend toward higher $\delta^{13} \mathrm{C}_{\text {DIC }}$ with increasing meltwater contribution is seen in some datasets. This pattern may be related to the notion that sea-ice meltwater adds nutrients to the water column and, thereby, enables biological production and also adds to the DIC pool [40]. However, there is no indication of an effect of sea-ice formation and thus sea-ice related brines on $\delta^{13} \mathrm{C}_{\mathrm{as}}$. High fractions of sea-ice formation are seen in the halocline layers of the Eurasian Basin (Fig. 8, see Oden 91 data with negative $\mathrm{f}_{\mathrm{SIM}}$ of up to $\sim-8 \%$ ) and the Canada Basin (Fig. 8, see ESS-08 data with $\mathrm{f}_{\mathrm{SIM}}$ of up to $\sim-3 \%$ ). But while the fractions of sea-ice formation (neg $\mathrm{f}_{\mathrm{SIM}}$ values) vary strongly, $\delta^{13} \mathrm{C}_{\mathrm{DIC}}$ as well as $\delta^{13} \mathrm{C}_{\mathrm{as}}$ shows no trend.

\section{Summary and future directions}

In the Canada Basin, high $\delta^{13} \mathrm{C}_{\mathrm{DIC}}$ values at the surface appear to reflect the biological productivity signal and removal of light $\delta^{13} \mathrm{C}$ from the DIC pool, whereas low $\delta^{13} \mathrm{C}_{\text {DIC }}$ values deeper in the halocline (UHW and LHW) indicate the recycling of organic material. However, the evidence from $\delta^{13} \mathrm{C}_{\mathrm{DIC}}$ adjusted for global-scale, biological processes, $\delta^{13} \mathrm{C}_{\mathrm{as}}$, suggests a more complex picture, where $\delta^{13} \mathrm{C}_{\text {DIC }}$ values may be largely transported to the Canada Basin from the adjacent shelf areas. Further, low $\delta^{13} \mathrm{C}_{\text {DIC }}$ in the UHW and LHW at around 33.1 and 34.5 salinity, respectively, may not only be caused by the decay of organic material, but also by variable air-sea exchange processes under non-equilibrium conditions occurring primarily on the shelves under seasonal sea-ice conditions. Strong outgassing of $\mathrm{CO}_{2}$ and, thereby, enrichment of $\delta^{13} \mathrm{C}_{\text {DIC }}$ has been demonstrated for much of the East Siberian Sea [2], and the resulting high $\delta^{13} \mathrm{C}_{\mathrm{DIC}}$ signal is transported within the halocline into the Canada Basin. However, the invasion of light atmospheric $\mathrm{CO}_{2}$ resulting in light $\delta^{13} \mathrm{C}_{\mathrm{as}}$ values is also traceable along the continental slope and in the Canada Basin at higher salinities.

In the Eurasian Basin, $\delta^{13} \mathrm{C}_{\mathrm{DIC}}$ values show little variation. While biological productivity over the Barents Sea and northern Kara seas can be high, the signals of production and remineralization with high and low $\delta^{13} \mathrm{C}_{\mathrm{DIC}}$, respectively, are apparently not transported into the Eurasian Basin. This may be connected to a weaker stratification in the Eurasian Basin and sufficient degradation of any shelf-sourced biological signal potentially present in this region as shelf waters recirculating in the Eurasian Basin have a relatively long residence time of at least 8 years [39].

In addition to air-sea interaction, river water, sea-ice meltwater, and sea-ice related brine waters are potentially important non-biotic effects on $\delta^{13} \mathrm{C}_{\text {DIC }}$ in the Arctic Ocean. But while the extremely low- $\delta{ }^{13} \mathrm{C}_{\text {DIC }}$ river runoff signal is very prominent on the Siberian shelves [20], it does not significantly influence the overall $\delta^{13} \mathrm{C}_{\text {DIC }}$ 


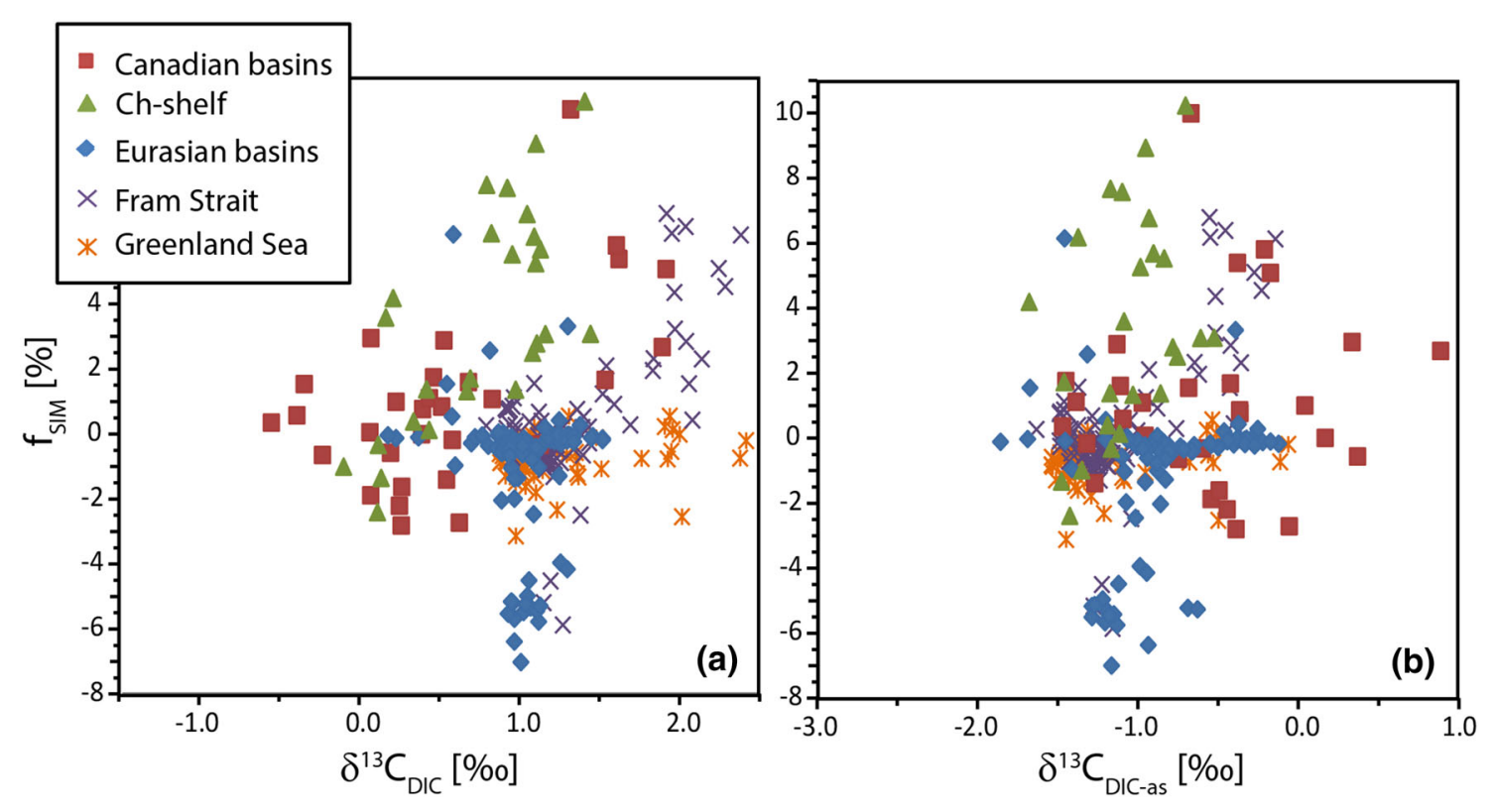

Fig. 8 Relation of $\delta^{13} \mathrm{C}_{\mathrm{DIC}}$ and $\delta^{13} \mathrm{C}_{\mathrm{DIC} \text {-as }}$ versus sea-ice meltwater fraction ( $\mathrm{f}_{\mathrm{SIM}}$; calculated with 3-component approach)

distribution within the Arctic basins and is only weakly visible_-if at all—within the Canada basin. We also find no evidence for any direct influence of sea-ice production on $\delta^{13} \mathrm{C}_{\text {DIC. }}$. While transport processes within the halocline clearly play an important role in the distribution of $\delta^{13} \mathrm{C}_{\mathrm{DIC}}$ within the Arctic Ocean, the fractions of river and sea-ice related waters, also transported within the halocline, show no significant effects on the $\delta^{13} \mathrm{C}_{\text {DIC }}$.

Our data are the first compilation of $\delta^{13} \mathrm{C}_{\text {DIC }}$ from the Arctic Ocean and are meant to serve as an initial baseline for this region. As Arctic sea ice and related environments are especially sensitive to a rapidly changing climate, Arctic Ocean $\delta^{13} \mathrm{C}_{\text {DIC }}$ values are prone to change in the near future. While our data show that sea-ice melt and formation processes have no strong direct influence on $\delta^{13} C_{\text {DIC }}$, our data nevertheless suggest that increasing river runoff and changing sea-ice conditions in the Arctic Ocean and on the Arctic shelves may still significantly impact the $\delta^{13} \mathrm{C}_{\text {DIC }}$ due to the indirect feedback mechanisms associated with changing biological activity and air-sea exchange.

When applied to paleo-climate studies, the presented $\delta^{13} \mathrm{C}_{\text {DIC }}$ data need to be further evaluated in the context of the surface ocean Suess effect. The sampling period of nearly 20 years adds an increased uncertainty due to a decrease of about $-0.5 \%$ in atmospheric $\delta^{13} \mathrm{C}$ values across the sampling interval. Within these limitations, our data may serve as a first useful $\delta^{13} \mathrm{C}_{\text {DIC }}$ baseline due to a total lack of further data from the Arctic Ocean water column. For example, high $\delta^{13} \mathrm{C}$ in planktic foraminifers from surface sediments in the Canada Basin [51] may be explained by the import of biologically mediated $\delta^{13} \mathrm{C}_{\text {DIC }}$ from the shelves, while pronounced low surface-sediment planktic $\delta^{13} \mathrm{C}$ along the shelf break of the Chuckchi and Beaufort seas [51] may be related to low $\delta^{13} C_{\text {DIC }}$ modified by air-sea exchange. Despite remaining substantial uncertainties with the application of surface-sediment stable isotope data to a more distant past, modern $\delta^{13} \mathrm{C}_{\text {DIC }}$ and $\delta^{18} \mathrm{O}$ data from the water column constitute an essential prerequisite for paleoclimatic reconstructions.

Acknowledgments We thank the captains and crews of the various ship-based expeditions and all other colleagues who assisted in sample collection and stable isotope measurements. We are thankful to A. Schmittner for commenting on an earlier version of the manuscript. Comments by two reviewers are gratefully acknowledged and helped to improve the study. The work was supported by the German Research Foundation DFG grant BA1638-1 to DB, and from the National Science Foundation NSF to LP and JDO (PLR-0520365).

\section{References}

1. Aksenov Y, Ivanov VV, Nurser AJG, Bacon S, Polyakov IV, Coward AC, Naveira-Garabato AC, Beszczynska-Moeller A (2011) The arctic circumpolar boundary current. J Geophys Res Oceans 116(C9):C09017. doi:10.1029/2010JC006637

2. Alling V, Porcelli D, Mörth C-M, Anderson LG, Sanchez-Garcia L, Gustafsson Ö, Andersson PS, Humborg C (2012) Degradation of terrestrial organic carbon, primary production and out-gassing of $\mathrm{CO}_{2}$ in the Laptev and East Siberian Seas as inferred from $\delta^{13} \mathrm{C}$ values of DIC. Geochim Cosmochim Acta 95:143-159. doi:10.1016/j.gca.2012.07.028

3. Anderson LG, Andersson PS, Björk G, Peter Jones E, Jutterström S, Wåhlström I (2013) Source and formation of the upper halocline of the Arctic Ocean. J Geophys Res Oceans 118(1):410-421. doi:10.1029/2012JC008291 
4. Anderson LG, Jutterström S, Hjalmarsson S, Wåhlström I, Semiletov IP (2009) Out-gassing of $\mathrm{CO}_{2}$ from Siberian Shelf seas by terrestrial organic matter decomposition. Geophys Res Lett 36(20):L20601. doi:10.1029/2009GL040046

5. Arrigo KR, van Dijken GL (2011) Secular trends in Arctic Ocean net primary production. J Geophys Res Oceans 116(C9):C09011. doi:10.1029/2011JC007151

6. Bauch D, Schlosser P, Fairbanks RF (1995) Freshwater balance and the sources of deep and bottom waters in the Arctic Ocean inferred from the distribution of $\mathrm{H}_{2}^{18} \mathrm{O}$. Prog Oceanogr 35:53-80

7. Bauch D, Carstens J, Wefer G, Thiede J (2000) The imprint of anthropogenic $\mathrm{CO}_{2}$ in the Arctic Ocean: evidence from planktonic $\delta^{13} \mathrm{C}$ data from watercolumn and sediment surfaces. Deep Sea Res II 47:1791-1808

8. Bauch D, Hölemann J, Willmes S, Gröger M, Novikhin A, Nikulina A, Kassens H, Timokhov L (2010) Changes in distribution of brine waters on the Laptev Sea shelf in 2007. J Geophys Res 115:C11008. doi:10.1029/2010JC006249

9. Bauch D, Gröger M, Dmitrenko I, Hölemann J, Kirillov S, Mackensen A, Taldenkova E, Andersen N (2011) Atmospheric controlled freshwater water release at the Laptev Sea Continental margin. Polar Res 30:5858. doi:10.3402/polar.v30i0.5858

10. Bauch D, Rutgers van der Loeff M, Andersen D, Torres-Valdes S, Bakker K, Abrahamsen EP (2011) Origin of freshwater and polynya water in the Arctic Ocean halocline in summer 2007. Prog Oceanogr 91:482-495. doi:10.1016/j.pocean.2011.07.017

11. Bauch D, Torres-Valdes S, Polyakov I, Novikhin A, Dmitrenko I, McKay J, Mix A (2014) Halocline water modification and alongslope advection at the Laptev Sea continental margin. Ocean Sci. 10(1):141-154. doi:10.5194/os-10-141-2014

12. Bauch HA, Erlenkeuser H, Bauch D, Mueller-Lupp T, Taldenkova E (2004) Stable oxygen and carbon isotopes in modern benthic foraminifera from the Laptev Sea shelf: implications for reconstructing proglacial and profluvial environments in the Arctic. Mar Micropaleontol 51(3-4):285-300. doi:10.1016/j.mar micro.2004.01.002

13. Bekryaev RV, Polyakov IV, Alexeev VA (2010) Role of polar amplification in long-term surface air temperature variations and modern Arctic warming. J. Climate 23(14):3888-3906. doi:10. 1175/2010JCLI3297.1

14. Broecker WS (1974) "NO," A conservative water mass tracer. Earth Planet Sci Lett 23:100-107

15. Carmack E, Wassmann P (2006) Food webs and physical-biological coupling on pan-Arctic shelves: unifying concepts and comprehensive perspectives. Prog Oceanogr 71(2-4):446-477. doi:10.1016/j.pocean.2006.10.004

16. Comiso JC, Parkinson CL, Gersten R, Stock L (2008) Accelerated decline in the Arctic sea ice cover. Geophys Res Lett 35:L01703. doi:10.1029/2007GL031972

17. Cooper LW, Cota GF, Pomeroy LR, Grebmeier JM, Whitledge TE (1999) Modification of NO, PO, and NO/PO during Flow across the Bering and Chukchi Shelves: Implications for Use as Arctic Water Mass Tracers. J Geophys Res 104:7827-7836

18. Ekwurzel B, Schlosser P, Mortlock R, Fairbanks R (2001) River runoff, sea ice meltwater, and Pacific water distribution and mean residence times in the Arctic Ocean. J Geophys Res 106(C5):9075-9092

19. Erlenkeuser H, TRANSDRIFT II Shipbord Scientific Party (1995) Stable carbon isotope ratios in the waters of the Laptev Sea/Sept. 94, Berichte zur Polarforschung, vol 176. AWI, Bremerhaven, Germany, pp 170-177

20. Erlenkeuser H, Cordt HH, Simstich J, Bauch D, Spielhagen RF (2003) DIC stable carbon isotope pattern in the surface waters of the southern Kara Sea, September 2000, in Siberian river run-off in the Kara Sea; characterisation, quantification, variability and environmental significance. In: Stein R, Fahl K, Fuetterer D,
Galimov E, Stepanets O (eds) Proceedings in Marine Science. Elsevier, Amsterdam, pp 91-110

21. Grebmeier JM (2012) Shifting Patterns of Life in the Pacific Arctic and Sub-Arctic Seas, edited by C. A. Carlson and S. J. Giovannoni. Annu Rev Mar Sci 4:63-78. doi:10.1146/annurevmarine-120710-100926

22. Griffith DR, McNichol AP, Xu L, McLaughlin FA, Macdonald RW, Brown KA, Eglinton TI, Herndl G (2012) Carbon dynamics in the western Arctic Ocean: insights from full-depth carbon isotope profiles of DIC, DOC, and POC. Biogeosciences 9(3)

23. Gordienko PA, Laktionov AF (1969) Circulation and physics of the Arctic Basin waters. Ann Int Geophys Year Oceanogr 46:94-112

24. Holland MM, Bitz CM (2003) Polar amplification of climate change in coupled models. Clim Dyn 21(3-4):221-232. doi:10. 1007/s00382-003-0332-6

25. Hunt GL, Blanchard AL, Boveng P, Dalpadado P, Drinkwater KF, Eisner L, Hopcroft RR, Kovacs KM, Norcross BL, Renaud P, Reigstad M, Renner M, Skjoldal HR, Whitehouse A, Woodgate RA (2013) The Barents and Chukchi Seas: comparison of two Arctic shelf ecosystems. J Mar Syst 109-110:43-68. doi:10.1016/ j.jmarsys.2012.08.003

26. Jones E, Anderson L, Swift J (1998) Distribution of Atlantic and Pacific water in the upper Arctic Ocean: implications for circulation. Geophys Res Lett 25(6):765-768

27. Lynch-Stieglitz J, Stocker TF, Broecker W, Fairbanks RG (1995) The influence of air-sea exchange on the isotopic composition of oceanic carbon: observation and modeling. Global Biogeochem Cycles 9(4):653-665

28. Mackensen A (2013) High epibenthic foraminiferal $\delta^{13} \mathrm{C}$ in the Recent deep Arctic Ocean: implications for ventilation and brine release during stadials. Paleoceanography 28(3):574-584. doi:10. 1002/palo.20058

29. Martin S, Cavalieri DJ (1989) Contributions of the Siberian Shelf polynyas to the Arctic Ocean intermediate and deep water. J Geophys Res 94(C9):12725-12738

30. Mook WG, Bommerson JC, Staverman WH (1974) Carbon isotope fractionation between dissolved bicarbonate and gaseous carbon dioxide. Earth Planatary Sci Lett 22:169-176

31. Newton R, Schlosser P, Martinson DG, Maslowski W (2008) Freshwater distribution in the Arctic Ocean: simulation with a high resolution model and model-data comparison. J Geophys Res 113(C05024). doi:10.1029/2007JC004111

32. Newton R, Schlosser P, Mortlock R, Swift J, MacDonald R (2013) Canadian Basin freshwater sources and changes: results from the 2005 Arctic Ocean Section. J Geophy Res Oceans 118(4):2133-2154. doi:10.1002/jgrc.20101

33. Ortiz JD, Mix AC, Wheeler PA, Key RM (2000) Anthropogenic $\mathrm{CO}_{2}$ invasion into the northeast Pacific based on concurrent $\delta^{13} \mathrm{C}_{\mathrm{DIC}}$ and nutrient profiles from the California Current. Global Biogeochem Cycles 14(3):917-929. doi:10.1029/1999GB 001155

34. Östlund H, Hut G (1984) Arctic Ocean water mass balance from isotope data. J Geophys Res 89(C4):6373-6381

35. Pabi S, van Dijken GL, Arrigo KR (2008) Primary production in the Arctic Ocean, 1998-2006. J Geophys Res Oceans 113(C8): C08005. doi: 10.1029/2007JC004578

36. Pipko I, Semiletov I, Tishchenko PY, Pugach S, Christensen J (2002) Carbonate chemistry dynamics in Bering Strait and the Chukchi Sea. Prog Oceanogr 55(1-2):77-94. doi:10.1016/S00796611(02)00071-X

37. Polyak L, Jakobsson M (2011) Quaternary sedimentation in the Arctic Ocean: recent advances and further challenges. Oceanography 24(3):52-64

38. Rudels B, Anderson LG, Jones EP (1996) Formation and evolution of the surface mixed layer and halocline of the Arctic 
Ocean. J Geophys Res Oceans 101(C4):8807-8821. doi:10.1029/ 96JC00143

39. Rutgers van der Loeff M, Cai P, Stimac I, Bauch D, Hanfland C, Roeske T, Moran SB (2012) Shelf-basin exchange times of Arctic surface waters estimated from $228 \mathrm{Th} / 228 \mathrm{Ra}$ disequilibrium. J Geophys Res117(C03024). doi:10.1029/2011JC007478

40. Rysgaard S, Glud RN, Sejr MK, Bendtsen J, Christensen PB (2007) Inorganic carbon transport during sea ice growth and decay: a carbon pump in polar seas. J Geophys Res Oceans 112(C3):C03016. doi:10.1029/2006JC003572

41. Sambrotto RN, Goering JJ, McRoy CP (1984) Large yearly production of Phytoplankton in the Western Bering Strait. Science 225(4667):1147-1150. doi:10.1126/science.225.4667.1147

42. Schlosser P, Bauch D, Bönisch G, Fairbanks RF (1994) Arctic river-runoff: mean residence time on the shelves and in the halocline. Deep-Sea Res I 41(7):1053-1068

43. Schmittner A, Gruber N, Mix AC, Key RM, Tagliabue A, Westberry TK (2013) Biology and air-sea gas exchange controls on the distribution of carbon isotope ratios $\left(\delta^{13} \mathrm{C}\right)$ in the ocean. Biogeosciences 10(9):5793-5816

44. Semiletov IP, Pipko II, Repina I, Shakhova NE (2007) Carbonate chemistry dynamics and carbon dioxide fluxes across the atmosphere-ice-water interfaces in the Arctic Ocean: pacific sector of the Arctic. J Mar Syst 66(1-4):204-226. doi:10.1016/j.jmarsys. 2006.05.012

45. Slagstad D, Ellingsen IH, Wassmann P (2011) Evaluating primary and secondary production in an Arctic Ocean void of summer sea ice: an experimental simulation approach. Prog Oceanogr 90(1-4):117-131. doi:10.1016/j.pocean.2011.02.009
46. Spielhagen RF, Erlenkeuser H (1994) Stable oxygen and carbon isotopes in planktic foraminifers from Arctic ocean surface sediments: reflection of the low salinity surface water layer. Mar Geol 119:227-250

47. Stroeve JC, Kattsov V, Barrett A, Serreze M, Pavlova T, Holland M, Meier WN (2012) Trends in Arctic sea ice extent from CMIP5, CMIP3 and observations. Geophys Res Lett 39 (16):L16502. doi:10.1029/2012GL052676

48. Volkmann R, Mensch M (2001) Stable isotope composition $\left(\delta^{18} \mathrm{O}, \delta^{13} \mathrm{C}\right)$ of living planktic foraminifers in the outer Laptev Sea and the Fram Strait. Mar Micropaleontol 42:163-188

49. Wallace DWR, Schlosser P, Krysell M, Bönisch G (1992) Halocarbon ratio and tritium $/{ }^{3} \mathrm{He}$ dating of water masses in the Nansen Basin, Arctic Ocean, Deep Sea Research Part A. Oceanographic Research Papers 39(2, Part 1):S435-S458. doi:10. 1016/S0198-0149(06)80015-4

50. Wassmann P, Reigstad M (2011) Future Arctic Ocean seasonal ice zones and implications for pelagic-benthic coupling. Oceanography 24:220-231. doi:10.5670/oceanog.2011.74

51. Xiao W, Wang R, Polyak L, Astakhov A, Cheng X (2014) Stable oxygen and carbon isotopes in planktonic foraminifera Neogloboquadrina pachyderma in the Arctic Ocean: an overview of published and new surface-sediment data. Mar Geol 352:397-408

52. Yamamoto-Kawai M, McLaughlin FA, Carmack EC, Nishino S, Shimada K (2008) Freshwater budget of the Canada Basin, Arctic Ocean, from salinity, $\delta^{18} \mathrm{O}$, and nutrients. J Geophys Res 113(C01007). doi:10.1029/2006JC003858 